\title{
Evaluation of an immunochromatography test for malaria diagnosis under different storage conditions
}

\author{
Avaliação de um teste de imunocromatografia para o diagnóstico \\ de malária em diferentes condições de estocagens
}

\author{
Roberta de Souza Rodrigues Penhalbel ${ }^{1}$, Érica Fugikaha ${ }^{1}$, Alexandre Lorenzetti ${ }^{1}$, Renata Tomé Alves ${ }^{1}$, \\ Carlos Eugênio Cavasini ${ }^{1}$, Andréa Regina Baptista Rossit ${ }^{1}$, Vanja Suely Pachiano Calvosa ${ }^{2}$, \\ Álvaro Augusto D‘Almeida Couto ${ }^{3}$ and Ricardo Luiz Dantas Machado ${ }^{1}$
}

\begin{abstract}
This study aimed to evaluate the second-generation OptiMal test for malaria diagnosis under various storage conditions. It detected all the positive samples, except for two Plasmodium malariae samples. Further research evaluating diverse environmental conditions are important for ICT test applicability in Brazilian malaria areas.
\end{abstract}

Key-words: Malaria. Plasmodium sp. Diagnosis. Immunochromatography.

\section{RESUM0}

Este estudo objetiva avaliar o desempenho do teste OptiMal de segunda geração para o diagnóstico de malária em diferentes condições de estocagem. Ele detectou todas as amostras positivas, exceto duas amostras de Plasmodium malariae. Futuras pesquisas avaliando as diversas condições ambientais são importantes para a aplicabilidade do ICT em áreas de malária brasileira.

Palavras-chaves: Malária. Plasmodium sp. Diagnóstico. Imunocromatografia.

Malaria is endemic in the Brazilian Amazon region. Of the four known human malaria parasites, Plasmodium falciparum, Plasmodium vivax, Plasmodium malariae and Plasmodium ovale, only the first three species have been detected in Brazil. The immense area of land and water, and the uncontrolled occupation of the Brazilian Amazon region, associated with the lack of personnel to carry out rapid diagnosis, all contribute to the elevated number of malaria cases in this region ${ }^{2}$. Rapid and accurate diagnosis of malaria is essential for reducing morbidity and mortality as well as for control purposes. Laboratory diagnosis of malaria has traditionally relied upon identification of the protozoan in peripheral blood using microscopic examination of thick and thin blood smears ${ }^{10}$. This procedure is labor-intensive, time consuming and dependent on training and expert knowledge, particularly for the interpretation of mixed infections and in cases with low parasitemias ${ }^{14}$.

During the last few years, alternative immunochromatography tests (ICT) have been developed showing potential for enhancing speed and accuracy in the diagnosis of both falciparum and vivax malaria, particularly where diagnostic tests are not available, such as in rural and remote areas ${ }^{8}$. Newer ICTs make use of a second pan-malarial antibody, which is supposed to detect all four malarial species that infect humans. The OptiMal test (Flow, USA), which is currently marketed by DiaMed, Switzerland, detects a Plasmodium falciparum-specific lactate dehydrogenase ( $\mathrm{LDH}$ ) and a second-generation $\mathrm{pLDH}$ common to all human malaria parasites ${ }^{3}$. The purpose of the present study was to evaluate the diagnostic performance of the $\mathrm{pLDH}$ for diagnosis under various storage conditions.

\footnotetext{
1. Departamento de Doenças Dermatológicas Infecciosas e Parasitárias da Faculdade de Medicina de São José do Rio Preto, São José do Rio Preto, SP. 2. Seção de Parasitologia do Instituto Evandro Chagas da Secretaria de Vigilância em Saúde do Ministério da Saúde, Belém, PA. 3. Gerência de Projeto e Pesquisa em Ensino-GPEPS-SES Macapá, AP.

Financial support was provided by FAPESP (02/09546-1) and CNPq (302353/03-8). The protocol for this study was reviewed and approved by the Research Board of the Faculty of Medicine of São José do Rio Preto (1246/2003).

Address to: Dr. Ricardo Luiz Dantas Machado. Centro de Investigação de Microrganismos/FMSJRP. Av. Brigadeiro Faria Lima 5416, 15090-000, São José do Rio Preto, SP.

Tel: 55172105700 ramal 5887

e-mail: ricardomachado@ famerp.br

Recebido para publicação em 8/9/2004

Aceito em 13/12/2004
} 
A total of 111 positive (75 Plasmodium vivax, 34 Plasmodium falciparum and 2 Plasmodium malariae) and 40 negative samples analyzed by the thick blood smear method were also evaluated using the OptiMal test (according to manufacturer's instructions). The samples from P. vivax malaria patients showed parasite density between 250 and 5,500 infected red blood cells $/ \mathrm{mm}^{3}$, while in P. falciparum samples the parasitemia ranged from 465 to 7,500 infected red blood cells/ $\mathrm{mm}^{3}$. Two samples of P. malariae showed parasite density below 50 infected red blood cells/ $\mathrm{mm}^{3}$. The OptiMal-IT kits ( DiaMedID AS) were stored at three different temperatures $\left(25^{\circ} \mathrm{C}, 30^{\circ} \mathrm{C}\right.$ and $39^{\circ} \mathrm{C}$ ) for 24,48 and 72 hours before use.

The OptiMal-IT kit provided negative results in all 40 samples with no parasites in the microscopy examination ( control group). The test could detect the positive samples that were seen in the microscopy examination atall evaluated temperatures and periods of storage. It was observed that the pink-line signals indicating positive results were constant under the same conditions. We could not detect either of the two P. malariae samples at any of the different temperatures and storage periods for the kits.

Notable antigens for the diagnosis of malaria are histidinerich protein II and lactate dehydrogenase, which are expressed in merozoite-staged malaria, secreted to erythrocyte cytoplasm or passively diffuse to human plasma ${ }^{5}$. Itis a crucial issue to consider the possible decline in test quality due to reduced shelf life under tropical conditions. Good stability and durability of the test strips were previously indicated for the ParaSight-F dipstick test after one year of storage at room temperature ${ }^{6}$. Recently, Figueiredo Filho etal ${ }^{2}$ evaluated the ICT Malaria Pf/ $/ \mathrm{Pv}^{\mathrm{TM}}$ (histidine-rich protein antigen II- AMRAD, Australia) storage at three different temperatures $\left(25^{\circ} \mathrm{C}, 30^{\circ} \mathrm{C}\right.$ and $\left.37^{\circ} \mathrm{C}\right)$ for 24 hours before use, and observed that the color of positive results ( pink line) loses its intensity as the temperature increased, which constitutes a limitation for its use. On the other hand, the OptiMal-IT manufacturer's recommendation is to use the test kit within a maximum of three months when stored under ambient conditions. Nevertheless, storage conditions are an important factor for the efficiency of the ICT, especially in the north of Brazil (Amazon region) were temperatures often surpass $30^{\circ} \mathrm{C}$.

Our results show excellent performance of the OptiMal-IT test under the differentconditions evaluated. However we could notdetect samples of $\mathrm{P}$. malariae, probably because of its well-recognized ability to detect mainly the most pathogenic human malaria P. falciparum and P. vivax infections ${ }^{3}$. Another reliable explanation is the fact that these samples showed low parasitemia which is a limitation advised by the manufacturer, stating that the test may not be a hundred percent correct in samples with parasitaemias under $<100$ red blood cells $/ \mathrm{mm}^{3}$. Additionally, previous studies ${ }^{37}$ have demonstrated that OpitMal-IT test is unreliable for detection of Plasmodium ovale and Plasmodium malariae.

The ICTs are known for their easy use, even by inexperienced personnel ${ }^{10}$. Future studies with the same format as that used in the present work are necessary. Our data suggest that OptiMalIT test can be used to perform malaria diagnosis in the Brazilian Amazon region, despite the high temperatures. Further research into diverse environmental conditions, such as humidity, are of great importance for establishment of ICT test applicability in Brazilian endemic and nonendemic malaria areas.

\section{ACKNOWLEDGEMENTS}

To all patients enrolled in this study.

\section{REFERENCES}

1. Araz E, Tanyhhksel M, Ardic N, Tabuk C. Performance of a commercial immunochromatographic test for the diagnosis of vivax malaria in Turkey. Transactions of the Royal Society of Tropical Medicine and Hygiene 94, 55-56, 2000.

2. Figueredo Filho AF, Fuigueredo MC, Nascimento JM, Calvosa VSP, Póvoa MM, Machado RLD. Performance of an immunochromatography test for vivax malaria in the Amazon region. Revista de Saúde Pública 37: 390-392, 2003.

3. Grobusch MP, Hänscheid T, Zoller T, Jelinek T, Burchard GD. Rapid immunochromatographic malarial antigen detection unreliable for detecting Plasmodium malariae and Plasmodium ovale. European Journal of Clinical Microbiology and Infectious Diseases 21: 818-820, 2002.

4. Humar A, Ohrt C, Harrington MA, Pillai D, Kain KC. ParaSight ${ }^{\mathrm{TM}}-\mathrm{F}$ test compared with the polymerase chain reaction and microscopy for the diagnosis of Plasmodium falciparum malaria in travelers. The American Journal of Tropical Medicine and Hygiene 56: 44-48, 1997.

5. Kenerman P, Dickson H, Luzzi GA. Plasma lactate dehydrogenase estimation in the diagnosis of malaria. Annals of Tropical Medicine and Parasitology 286: 563-565, 1992.

6. Mengesha T, Gebreselassie H, Mohammed H, Assefa T. Woldemichael T. ParaSight- F dipstick antigen test in the diagnosis of falciparum malaria in Ethiopia. East African Medical Journal 76: 626-629, 1990.

7. Moody A. Rapid diagnosis tests for malaria parasites. Clinical and Microbiology Review 15: 66-78, 2002.

8. Moody A, Hunt-Cooke A, Gabbett E, Chiodini P. Performance of the Optimal malaria antigen capture dipstick for malaria diagnosis and treatment monitoring at the Hospital for Tropical Diseases, London. British Journal of Haematology 109: 891-894, 2000.

9. Parra ME, Evans CB, Taylor DW. Identification of Plasmodium falciparum histidine-rich protein 2 in the plasma of humans with malaria. Journal of Clinical and Microbiology 29: 1629-1634, 1991.

10. Pieroni P, Mills CD, Ohrt C, Harrington MA, Kain KC. Comparison of the ParaSight ${ }^{\mathrm{TM}}$ - $F$ test with the polymerase chain reaction for the diagnosis of Plasmodium falciparum malaria in travelers. Transactions of the Royal Society of Tropical Medicine and Hygiene 92: 166-169, 1998. 